\title{
EQUiLIBRIUM
}

Quarterly Journal of Economics and Economic Policy

2015 VOLUME 10 ISSUE 2, June

p-ISSN 1689-765X, e-ISSN 2353-3293

www.economic-policy.pl

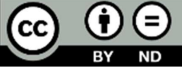

Pieloch-Babiarz, A. (2015). Catering Approach to the Dividend Payment Policy on the Warsaw Stock Exchange. Equilibrium. Quarterly Journal of Economics and Economic Policy, 10(2), pp. 185-206, DOI: http://dx.doi.org/10.12775/ EQUIL.2015.019

\author{
Aleksandra Pieloch-Babiarz*
}

University of Łódź, Poland

\section{Catering Approach to the Dividend Payment Policy on the Warsaw Stock Exchange**}

JEL Classification: $G 02 ; G 10 ; G 35$

Keywords: catering theory of dividends; dividend policy; propensity to pay dividend; behavioural finance

\begin{abstract}
Dividend payment policy is a significant issue of neoclassical theories of finance. One of the concepts which poses a challenge to the neoclassical approach to dividend payment policy is behavioural finance, including a catering theory of dividends.

The aim of the article is to examine whether and to what extent the catering theory of dividends is reflected in the behaviour of shareholders and managers on the WSE. The opportunity to accomplish the aim of this paper was conditioned by the empirical verification of research hypothesis stipulating that the number of dividend payers increases if the dividend payers are priced by the capital market higher that the nonpayers.

The empirical verification of hypothesis was conducted basing on the equaland value-weighted dividend premium as well as dividend payment ratios. Moreover, descriptive statistics, Spearman's rank correlation coefficient, linear regression and coefficient of determination were used. The study was carried out on the basis of companies operating in the electromechanical industry sector that were
\end{abstract}

(C) Copyright Institute of Economic Research \& Polish Economic Society Branch in Toruń Date of submission: December 19, 2014; date of acceptance: May 9, 2015

* Contact: apieloch@uni.lodz.pl, University of Lódź, Faculty of Economics and Sociology, Department of Business Analysis and Strategy, Łódź, 90-214, ul. Rewolucji 1905 r. nr 41, Poland 
listed on the WSE in the period between 1999-2013. The figures were taken from the Stock Exchange Yearbooks, Notoria Serwis database and GPWInfostrefa platform.

The preliminary results of empirical research in the range of the catering theory of dividends allow to draw a conclusion that this theory may be useful in explaining the dividend policy conducted by electromechanical industry companies listed on the WSE.

\section{Introduction}

The issues of net profit distribution are among the most significant strategic decisions made at the general meeting of shareholders. The division of net profit determines the conditions for the existence and development of the company and the growth of its competitiveness. Moreover, it is associated with the changes in the market value of the company. The dividend policy remains an issue that is not fully examined and explained by the theory, despite its significant impact on the capital market reaction and the future of company. The concept of dividend puzzle is being discussed not only by the neoclassical theory of finance, but more and more often it is explained by behavioural finance. Behavioural theories - including the catering theory of dividends - denying the assumption of capital market efficiency search for the new ways of explanation of capital market phenomena and complement the neoclassical theories by a new approach based on the irrational behaviour of managers or investors.

Assuming that the managers of stock companies behave in a rational way and investors categorize the companies in terms of dividend payment, we set the aim of the paper. This aim is to examine whether and to what extent the catering theory of dividends is reflected in the behaviour of the shareholders and managers on the Polish capital market. The opportunity to accomplish the objective of the paper was conditioned by the empirical verification of the research hypothesis stipulating that the number of dividend payers increases if the dividend payers are priced by the capital market higher that the nonpayers. Such a formulation of the research hypothesis results from the behavioural aspects of the stakeholders activities, in particular the managers and investors behaviour. When investors behave irrationally (i.e. they categorize companies taking into consideration only the criterion of dividend payment, not including company's investment opportunities), rational managers should recommend to the general meeting of shareholders a continuation of the dividend payments or an initiation of dividend in order to increase the market value of the company. 


\section{The Essence and Place of Catering Theory Among the Dividend Payment Theories - a Literature Review}

As part of the neoclassical theory of finance we should distinguish three main approaches to dividend policy. They are: neutral approach, prodividend approach and anti-dividend approach (Damodaran, 2007, p. 1013; Duraj, 2002, p. 124-137; Sierpińska, 1999, p. 131-151).

The representatives of neutral approach are Miller \& Modigliani (1961, pp. 411-433) who proposed the dividend irrelevance theory. These authors, assuming a strong market efficiency as well as the lack of taxes and transaction costs, concluded that the dividend policy does not affect the market value of the company. Moreover, the investors are indifferent whether they receives income in the form of dividend or capital gains. According to the dividend irrelevance theory, the only factors that affects the market value of the company are the investment opportunity and company's ability to growth.

According to the pro-dividend approach, an increase in the level of dividend is usually comprehended by investors as a positive signal sent by the company, indicating its good financial condition. An announcement of dividend payment leads to the increase in demand for shares and, consequently, to the growth in the market value of the company. According to Gordon (1959, pp. 99-105) dividend payment is also supported by the fact that along with the increase in the level of retained earnings cost of equity increases because investors require an additional premium for investment risk associated with the uncertainty of their future income. The uncertain future investment situation makes that the shareholders prefer dividend payment in regard to the possibility of achieving the potential capital gains in the indefinite future (Lintner, 1962, pp. 243-269).

The representatives of anti-dividend approach believe that the dividend payment has a negative impact on the market value of the company. The reasons for this are perceived in a different taxation of dividends and capital gains. If the dividend is taxed at the higher income tax rate than capital gains, the shareholders are not interested in dividend and prefer to retain the net profit (Litzenberger \& Ramaswamy, 1979, pp. 163-195).

Among the neoclassical theories of dividend are also these considering the signalling theory and information asymmetry theory (see Asquith \& Mullins, 1983, pp. 77-96; Pieloch-Babiarz, in print), agency theory (see Easterbrook, 1984, pp. 650-659; Jensen, 1986, pp. 323-329), the organizational life cycle (see Mueller, 1972, pp. 199-219; Grullon et al., 
2002, pp. 387-424) and clientele effect (Dhaliwal et al., 1999, pp. 179194).

By contrast, Baker \& Wurgler (2004a, pp. 1125-1165; 2004b, pp. 271-288) proposed a catering theory of dividends. This theory assumes that the behaviour of stock market investors is irrational. They categorize the companies taking into consideration only one factor - a dividend payment. When deciding, investors are focused solely on the fact of dividend payment. They do not pay attention to the amount of dividend payment as well as to the business development opportunities, the financial condition of the company, the size of its assets, the development stage of enterprise or the sector in which it operates. Therefore, investors divide the companies into two groups: dividend payers and non-payers. In turn, the managers behave in a rational way. They analyse the market reactions adjusting the dividend payment policy to the changes in investor sentiment to dividend payers. The managers respond to the stock market investors' needs paying the dividend if the market value of dividend payers is high and omitting the dividend payments if the market value of nonpayers is high (see Konieczka \& Szyszka, 2013, pp. 175-188). It should be added that the catering theory of dividends may be treated as an amplification of propensity to pay dividend concept formulated by Fama \& French (2001, pp. 3-43).

The catering theory of dividends has been confirmed mainly in the US market. Baker \& Wurgler (2004a, pp. 1125-1165) - introducing the concept of dividend premium, defined as a difference in the average market-to-book value ratios of dividend payers and nonpayers - proved that the number of dividend payers is strongly correlated with the level of dividend premium. The similar findings were derived from the studies conducted among stock companies in the UK (see Ferris et al., 2006, pp. 1149-1173). However, the catering theory of dividends has not been proven on the Japanese market (Tsuju 2010, pp. 1-14) as well as on the most developed capital markets of the European Union (Eije \& Megginson, 2008, pp. 347-374). On the Polish capital market, preliminary research was conducted by Gajdka (2013, pp. 141-156). The results of his study did not confirm the occurrence of catering on the Warsaw Stock Exchange.

The catering theory of dividends is still being improved and expanded with additional factors that may determine the behaviour of stock market investors and shape the market value of the company. Li \& Lie (2006, pp. 293-308) extended the catering model of Baker \& Wurgler with the amount of dividend payment. They found that the companies increase the level of payment if the dividend premium increases. If the dividend premium decreases, companies reduce dividend payments and replace them with the share repurchasing. The issue of dividend substitution was also discussed 
by Jiang et al. (2013, pp. 36-50) who introduced the concept of repurchase premium. Their research showed that if this premium is positive (i.e. the companies that conduct share repurchasing are valued by investors higher than the dividend payers) managers replace dividend payments by share repurchasing. Similar results of empirical research were also obtained by Kulchania (2013, pp. 180-195).

Li \& Zhao (2008, pp. 673-694) extended the catering model with a variable describing the risk. They proved that when the capital market valuates the dividend payers, it considers the changes in stock market sentiment and investment risk. Their findings were confirmed by Hoberg \& Prabhala (2009, pp. 79-116) who observed that after the model's extension by adding individual and systematic risk the dividend premium ceased to be relevant. On this basis, they formulated the conclusion that the dividend premium is a measure of risk.

Denis \& Osobov (2008, pp. 62-82), in turn, proved that the propensity to pay dividend depends mainly on such factors as: the company's size, its development opportunities and its profitability. To less extent it depends on the level of dividend premium. Also, Julio \& Ikenberry (2004, pp. 89-100) drew attention to the size and age of the company. They showed that the effect of catering theory of dividend disappears if the model is extended with these two additional variables.

Another variable that may complement the model is legislation. Ferris et al. (2009, pp. 1730-1738) proved that the catering theory of dividends applies mainly to those legal systems that take good care of minority shareholders. This situation occurs, for example, in the Nordic countries. De Rooij \& Renneboog (2009, pp. 215-238) also focused on the legislation. These authors conducted research on the Dutch market. They proved that stock companies initiate dividend payments to compensate the minority investors for having few rights and decision possibilities.

\section{Methodology of the Research}

The empirical research was conducted basing on 41 companies operating in the electromechanical industry sector that were listed on the Warsaw Stock Exchange in the period between 2000-2013. Due to the methodology of research, the calculations were also carried out for 1999. The figures were taken from the Stock Exchange Yearbooks, Notoria Serwis SA database and GPWInfostrefa platform.

Empirical verification of the research hypothesis was conducted mainly on the basis of the methodology proposed by Baker \& Wurgler (2004a, p. 
1133). In the first stage of the study, we determined separately for each year the number of companies paying dividend (i.e. the companies initiating and continuing payments) as well as the number of companies not paying dividends (i.e. the companies omitting dividend payments and not paying dividend at all). Moreover, the structure of these companies was examined.

Then, the basic dividend payment ratios were calculated. We used three ratios proposed by Baker \& Wurgler (2004, p. 1133) and six author's ratios, including four total structure ratios (see Table 1). These additional ratios were added in the hope of a fuller study of the issue of shareholders' and managers' behaviour on the Warsaw trading floor.

Table 1. Basic dividend payment ratios

\begin{tabular}{|c|c|c|}
\hline $\begin{array}{l}\text { Dividend payment initia- } \\
\text { tion ratio }\end{array}$ & Init $_{t}$ & $\frac{\text { New Payers }_{t}}{\text { Total Nonpayers }_{t-1}-\text { Delist Nonpayers }_{t}}$ \\
\hline $\begin{array}{l}\text { Dividend payment contin- } \\
\text { uation ratio }\end{array}$ & Cont $_{t}$ & $\frac{\text { Old Payers }_{t}}{\text { Total Payers }_{t-1}-\text { Delist Payers }_{t}}$ \\
\hline $\begin{array}{l}\text { Dividend payment ratio of } \\
\text { newly listed companies }\end{array}$ & List $_{t}$ & $\frac{\text { List Payers }_{t}}{\text { List Payers }_{t}+\text { List Nonpayers }_{t}}$ \\
\hline $\begin{array}{l}\text { Dividend payment omis- } \\
\text { sion ratio }\end{array}$ & Omit $_{t}$ & 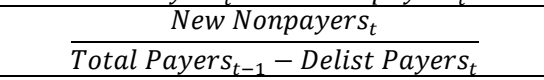 \\
\hline $\begin{array}{l}\text { Share of new dividend } \\
\text { payers in the number of } \\
\text { total payers }\end{array}$ & Init Share $_{t}$ & $\frac{\text { New Payers }_{t}+\text { List Payers }_{t}}{\text { Old Payers }_{t}+\text { New Payers }_{t}+\text { List Payers }_{t}}$ \\
\hline $\begin{array}{l}\text { Share of dividend payers in } \\
\text { a total number of compa- } \\
\text { nies in sector }\end{array}$ & Pay Total & $\frac{\text { Total Payers }_{t}}{\text { Total Payers }_{t}+\text { Total Nonpayers }_{t}}$ \\
\hline $\begin{array}{l}\text { Share of new payers in a } \\
\text { total number of companies } \\
\text { in sector }\end{array}$ & Init Total ${ }_{t}$ & $\frac{\text { New } \text { Payers }_{t}+\text { List Payers }_{t}}{\text { Total Payers }_{t}+\text { Total Nonpayers }_{t}}$ \\
\hline $\begin{array}{l}\text { Share of companies con- } \\
\text { tinuing dividend payments } \\
\text { in a total number of com- } \\
\text { panies in sector }\end{array}$ & Cont Total & $\frac{\text { Old Payers }_{t}}{\text { Total Payers }_{t}+\text { Total Nonpayers }_{t}}$ \\
\hline $\begin{array}{l}\text { Share of companies omit- } \\
\text { ting dividend payments in } \\
\text { a total number of compa- } \\
\text { nies in sector }\end{array}$ & Omit Total $_{t}$ & $\frac{\text { New Nonpayers }_{t}+\text { Delist Payers }_{t}}{\text { Total Payers }_{t}+\text { Total Nonpayers }_{t}}$ \\
\hline
\end{tabular}

\section{Symbols:}

Total Payerst - the companies paying dividend in year t, Total Nonpayerst - the companies not paying dividend in year $t$, New Payerst - the companies paying dividend in year $t$ and not paying it in year $t-1$, New Nonpayerst - the companies not paying dividend in year $\mathrm{t}$ and paying it in year $\mathrm{t}-1$, Old Payerst - the companies paying dividend in year $t$ and in year $t-1$, Old Nonpayerst - the companies not paying dividend in year $t$ and in year $t-1$, List Payerst - the companies paying dividend in year $t$ and not in the sample in year $t-1$, List Nonpayerst - the companies not paying dividend in year $\mathrm{t}$ and not in the sample in year t-1, Delist Payerst - the companies paying dividend and delisted in year $\mathrm{t}$, Delist Nonpayerst - the companies not paying dividend and delisted in year $\mathrm{t}$.

Source: own study on the basis of Baker \& Wurgler (2004, p. 1133). 
In the next stage of the study, the dividend premium was calculated. It was defined as a difference in the average price-to-book value ratios $(p / B V)$ of dividend payers and nonpayers. The dividend premium was calculated using two formulas, i.e. formula for equal- and value-weighted dividend premium (compare Kowerski, 2011, p. 91).

The formula for equal-weighted dividend premium in year $t$ is as follows:

$$
E W p_{t}^{D-N D}=\frac{1}{N P_{t}} \sum_{i=1}^{N P_{t}}\left(E W \frac{p}{B V}\right)_{i, t}-\frac{1}{N N_{t}} \sum_{n=1}^{N N_{t}}\left(E W \frac{p}{B V}\right)_{n, t}
$$

where:

$E W p_{t}{ }^{D-N D}$ - equal-weighted dividend premium at the end of year $t$,

$\left(E W \frac{p}{B V}\right)_{i, t}$ - the value of price-to-book ratio at the end of year $t$ for $i$ payer,

$\left(E W \frac{p}{B V}\right)_{n, t}-$ the value of price-to-book ratio at the end of year $t$ for $n$ nonpayer,

$N P_{t}$ - the number of payers in year $t$,

$N N_{t}$ - the number of nonpayers in year $t$.

The formula for the value-weighted dividend premium is as follows:

$$
V W p_{t}{ }^{D-N D}=\frac{1}{V P_{t}} \sum_{i=1}^{N P_{t}}\left[v p_{i, t}\left(V W \frac{p}{B V}\right)_{i, t}\right]-\frac{1}{V N_{t}} \sum_{n=1}^{N N_{t}}\left[v n_{n, t}\left(V W \frac{p}{B V}\right)_{n, t}\right]
$$

where:

$V W p_{t}{ }^{D-N D}$ - value-weighted dividend premium at the end of year $t$,

$\left(V W \frac{p}{B V}\right)_{i, t}$ - the value of price-to-book ratio at the end of year $t$ for $i$ payer,

$\left(V W \frac{p}{B V}\right)_{n, t}$ - the value of price-to-book ratio at the end of year $t$ for $n$ nonpayer,

$v p_{i, t}-$ capitalization at the end of year $t$ of $i$ payer's shares,

$v n_{n, t}$ - capitalization at the end of year $t$ of $n$ nonpayer's shares,

$V P_{t}$ - capitalization at the end of year $t$ of all payers,

$V N_{t}$ - capitalization at the end of year $t$ of all nonpayers,

$N P_{t}$ - the number of payers in year $t$,

$N N_{t}$ - the number of nonpayers in year $t$.

Next, we determined the median for the dividend premium (calculated according to both formulas) and divided the research period into the years of relatively high and relatively low dividend premium. The years of relatively high dividend premium are these years for which the dividend premium was higher than the median. Otherwise, it was the year of relatively low dividend premium. Assuming that the dividend payment decisions are based on the historical data it was supposed that the level of dividend pre- 
mium in one year affects the dividend payment decision in the following year.

In the next stage, the average values of dividend payment ratios for years of relatively high and relatively low dividend premium were compared. Moreover, medians and standard deviations were calculated. Then, we determined Spearman's rank correlation coefficient between the equaland value-weighted dividend premium and dividend payment ratios. These actions were undertaken in order to examine the occurrence of dependence between the relative market value of dividend payers and propensity to pay dividend.

In the last part of the study, four models of linear regression were used. These models describe the relationship between the dividend premium in year $t-1$ (calculated in two ways) and the value of Init, Cont, List and Omit ratios in year $t$ (see Table 2).

Table 2. Linear regression models for the catering theory of dividends

\begin{tabular}{|l|c|c|}
\hline \multicolumn{1}{|c|}{ Dependent variable } & \multicolumn{2}{|c|}{ Dividend premium } \\
\cline { 2 - 3 } & \multicolumn{1}{|c|}{ Equal-weighted } & Value-weighted \\
\hline $\begin{array}{l}\text { Dividend payment initia- } \\
\text { tion ratio }\end{array}$ & Init $_{t}=\alpha+\beta E W p_{t-1}^{D-N D}+\varepsilon_{\mathrm{t}}$ & Init $_{t}=\alpha+\beta V W p_{t-1}^{D-N D}+\varepsilon_{\mathrm{t}}$ \\
\hline $\begin{array}{l}\text { Dividend payment continu- } \\
\text { ation ratio }\end{array}$ & Cont $_{t}=\alpha+\beta E W p_{t-1}^{D-N D}+\varepsilon_{\mathrm{t}}$ & Cont $_{t}=\alpha+\beta V W p_{t-1}^{D-N D}+\varepsilon_{\mathrm{t}}$ \\
\hline $\begin{array}{l}\text { Dividend payment ratio of } \\
\text { newly listed companies }\end{array}$ & List $_{t}=\alpha+\beta E W p_{t-1}^{D-N D}+\varepsilon_{\mathrm{t}}$ & List $_{t}=\alpha+\beta V W p_{t-1}^{D-N D}+\varepsilon_{\mathrm{t}}$ \\
\hline $\begin{array}{l}\text { Dividend payment omis- } \\
\text { sion ratio }\end{array}$ & Omit $_{t}=\alpha+\beta E W p_{t-1}^{D-N D}+\varepsilon_{\mathrm{t}}$ & Omit $_{t}=\alpha+\beta V W p_{t-1}^{D-N D}+\varepsilon_{\mathrm{t}}$ \\
\hline
\end{tabular}

Source: own study.

\section{Characteristics of the Companies Operating in the Electromechanical Industry Sector in the Period Between 1999-2013}

In the majority of years of research period, among companies operating in the electromechanical industry sector dominated dividend nonpayers. Most of companies did not decide to conduct a dividends payment during the economic downturn, i.e. between 2007-2010. The successive increase in the number of dividend payers have been observed since 2007. In the last three years of the research period, the number of dividend payers and nonpayers was at a similar level. The only years in which relatively more com- 
panies conducted the dividend payment were 2011 and 2013 (14 and 15 companies, respectively). In the period between 1999-2013, a horizontal trend line was observed for nonpayers, while for the dividend payers linear trend was increasing (see Figure 1).

Figure 1. The number of dividend payers and nonpayers in electromechanical industry sector in the period between 1999-2013

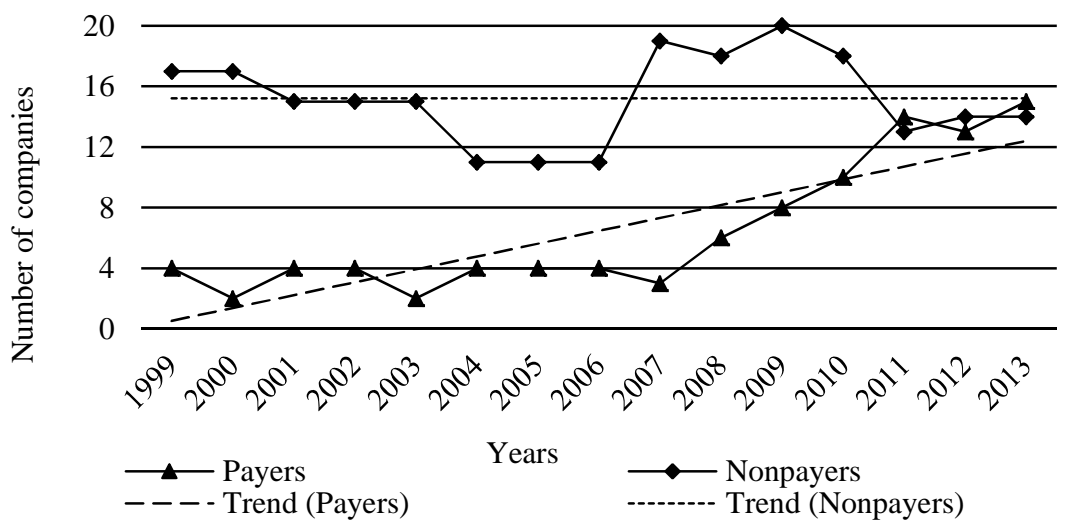

Source: own study on the basis of Stock Exchange Yearbooks, Notoria Serwis SA and GPWInfostrefa.

Among the dividend payers dominated those companies that were continuing dividend payments. This may denote the stability of dividend policy in the analysed sector. In 2003 and 2007, all companies that paid the dividend did the same in the previous year. It should be added that these were only 2 and 3 companies, respectively. The largest number of companies continued dividend payments in the last four years of research period. In 2010 , the share of companies continuing the dividend payments in a total number of dividend payers amounted to $70 \%$ (7 companies), in 2011 stood at 64\% (9 units), in 2012 was equal to 69\% (9 enterprises) and in 2013 reached the level of 60\% (9 companies). In 2001 and 2009, the share of companies continuing the dividend payment in a total number of analysed companies was the lowest. In 2001 it amounted to $25 \%$ and in 2009 it stood at $38 \%$ ( 1 and 3 companies, respectively).

The second largest group of dividend payers comprised of the companies that did not pay dividend in the previous year. Their largest share in total payers was observed in 2001 and amounted to 75\%. In 2004, 2008 and 2009 , this share stood at $50 \%$. The majority of companies, that in the previ- 
ous year did not pay dividend, decided to pay it in the last year of analysis, i.e. in 2013. It was 5 companies (33\% of the study group).

In the entire research period, only three companies that in a given year were newly listed on the main market of the Warsaw Stock Exchange (including those companies passing from NewConnect market), paid a dividend in the same year. In 2009 it was Centrum Klima SA, in 2011 it was Zamet Industry SA and in 2013 it was Newag SA. Only one company paid dividend and then, in the same year, was excluded from stock exchange trading. This occurred in 2012 (see Figure 2) and the company was Centrum Klima SA.

Figure 2. The number and structure of dividend payers in electromechanical industry sector in the period between 1999-2013

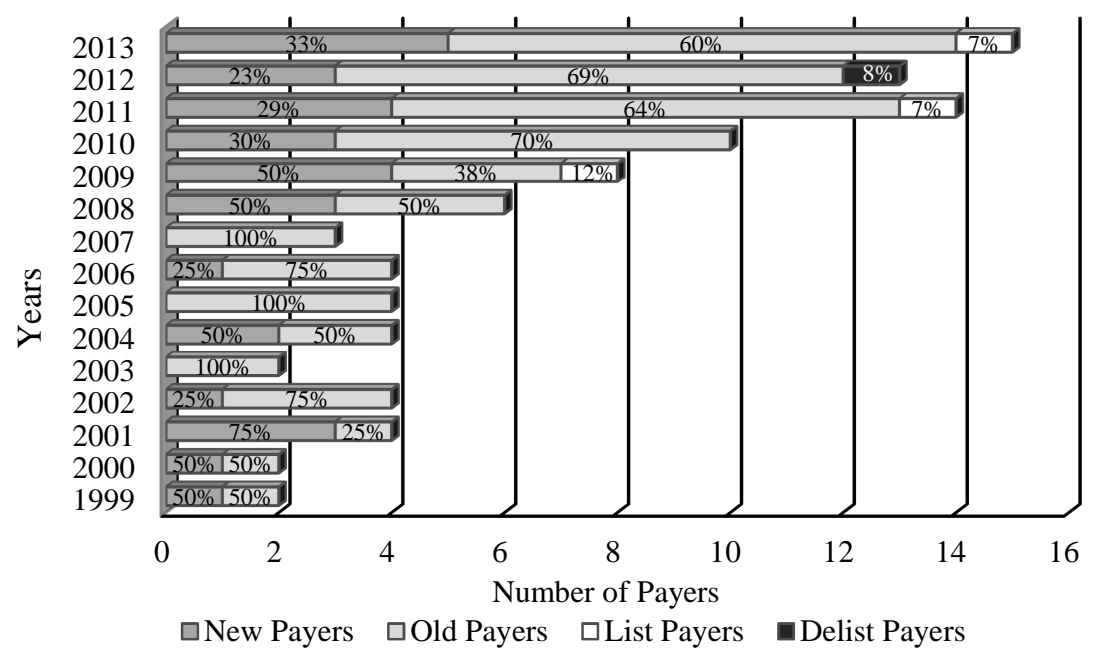

Source: own study on the basis of Stock Exchange Yearbooks and Notoria Serwis SA.

Among dividend non-payers dominated those companies that did not distribute cash to shareholders in the previous year. Most of such companies were observed in 2001 (93\% of the study population), in 2011 (86\%), in $2008(83 \%)$ and in 2010 (83\%). In 2008 and 2010, the majority of companies continued strategy of so called zero dividend payment policy (15 companies per year). Most companies omitted dividend payment in 2012 (4 cases) as well as in 1999, 2000 and 2009 (3 companies per year). However, in the 2004, 2005 and 2013 none of the companies paying dividend in the previous year decide to discontinue the payment. The largest number of 
newly listed companies that did not pay dividend was observed in 2007 (7 cases, accounting for $32 \%$ of nonpayers in this year). In 2008 and 2009, there were 3 such cases per year. In 2005 and 2013, we observed 2 such cases per year. Moreover, there were just a few companies that did not pay dividend and were delisted in the same year. In 2002, 2004 and 2010, there were two such cases per year, and in 2003, 2005, 2007 and 2013, we observed only one such case per year (see Figure 3 ).

Figure 3. The number and structure of dividend nonpayers in electromechanical industry sector in the period between 1999-2013

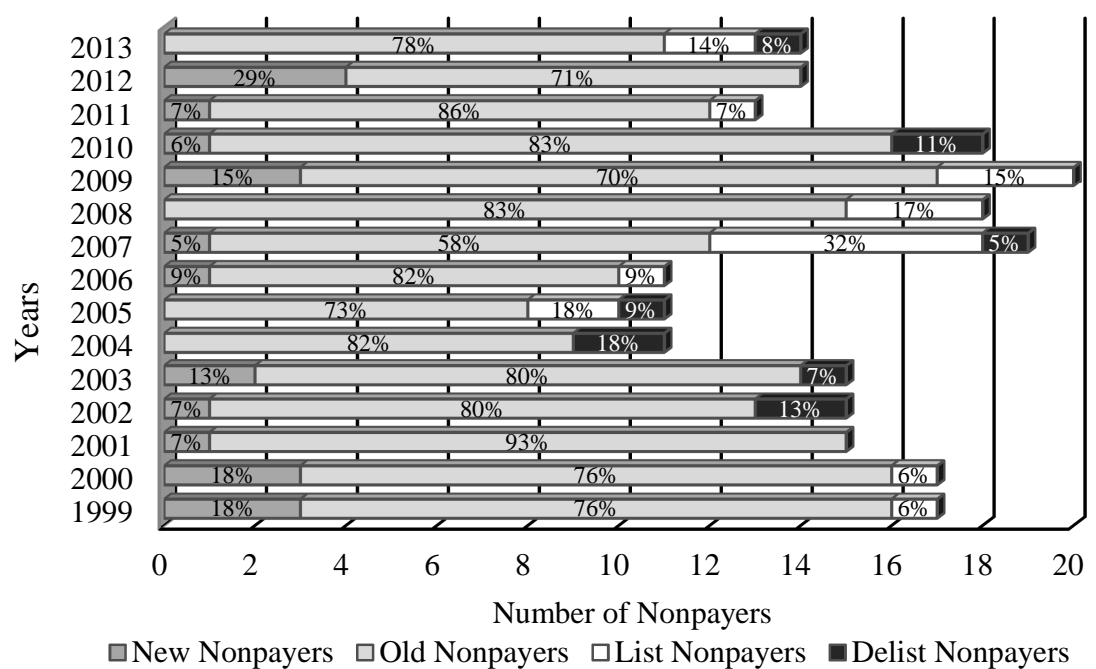

Source: own study on the basis of Stock Exchange Yearbooks and Notoria Serwis SA.

The highest percentage of companies initiating the dividend payment was observed in the last years of research period. Dividend payment initiation ratio reached the highest value in 2013 , when $38,46 \%$ of the previous nonpayers initiated dividend payments. In 2012, the value of Init $_{t}$ stood at $23,08 \%$, while in 2009 and 2011 this ratio amounted to $22,22 \%$ per year. The lowest value of this ratio was equal to $0 \%$. None of the previous nonpayers decided to initiate dividend in three last years of research period, i.e. in 2003, 2005 and 2007. The average annual dividend payment initiation ratio reached the level of $13,87 \%$, its standard deviation stood at $10,55 \%$ and median amounted to $15,59 \%$ (see Table 3 ). 
All companies paying the dividend in year $t-1$ decided to continue the payments in 2004-2005 and in 2008. The high value of dividend payment continuation ratio was observed in 2011 (this ratio amounted to 90\%) and in 2010 (this ratio reached the level of 87,5\%). In the last two years of the study the value of Cont $t$ amounted to $69,23 \%$ per year. In the period between 2000-2013 the average annual dividend payment continuation ratio stood at $72,57 \%$, median reached the level of $75 \%$ and standard deviation amounted to $21,74 \%$ (see Table 3 ).

Table 3. Measures of dividend payment in the period between 2000-2013 (in \%)

\begin{tabular}{|c|c|c|c|c|c|c|c|c|c|}
\hline \multirow[b]{2}{*}{ Years } & \multicolumn{9}{|c|}{ Dividend payment ratios } \\
\hline & Init $_{t}$ & Cont $_{t}$ & List $_{t}$ & Omit $_{t}$ & $\begin{array}{c}\text { Init } \\
\text { Share }_{t}\end{array}$ & $\begin{array}{c}\text { Pay } \\
\text { Total }_{t}\end{array}$ & $\begin{array}{c}\text { Init } \\
\text { Total }_{t}\end{array}$ & $\begin{array}{l}\text { Cont } \\
\text { Total }_{t}\end{array}$ & $\begin{array}{c}\text { Omit }_{\text {Total }} \\
\text { Tot }^{2}\end{array}$ \\
\hline 2000 & 5,88 & 25,00 & 0,00 & 75,00 & 50,00 & 10,53 & 5,26 & 5,26 & 15,79 \\
\hline 2001 & 17,65 & 50,00 & $\mathrm{x}$ & 50,00 & 75,00 & 21,05 & 15,79 & 5,26 & 5,26 \\
\hline 2002 & 7,69 & 75,00 & $\mathrm{x}$ & 25,00 & 25,00 & 21,05 & 5,26 & 15,79 & 5,26 \\
\hline 2003 & 0,00 & 50,00 & $\mathrm{x}$ & 50,00 & 0,00 & 11,76 & 0,00 & 11,76 & 11,76 \\
\hline 2004 & 15,38 & 100,00 & $\mathrm{x}$ & 0,00 & 50,00 & 26,67 & 13,33 & 13,33 & 0,00 \\
\hline 2005 & 0,00 & 100,00 & 0,00 & 0,00 & 0,00 & 26,67 & 0,00 & 26,67 & 0,00 \\
\hline 2006 & 9,09 & 75,00 & 0,00 & 25,00 & 25,00 & 26,67 & 6,67 & 20,00 & 6,67 \\
\hline 2007 & 0,00 & 75,00 & 0,00 & 25,00 & 0,00 & 13,64 & 0,00 & 13,64 & 4,55 \\
\hline 2008 & 15,79 & 100,00 & 0,00 & 0,00 & 50,00 & 25,00 & 12,50 & 12,50 & 0,00 \\
\hline 2009 & 22,22 & 50,00 & 25,00 & 50,00 & 62,50 & 28,57 & 17,86 & 10,71 & 10,71 \\
\hline 2010 & 16,67 & 87,50 & $\mathrm{x}$ & 12,50 & 30,00 & 35,71 & 10,71 & 25,00 & 3,57 \\
\hline 2011 & 22,22 & 90,00 & 50,00 & 10,00 & 35,71 & 51,85 & 18,52 & 33,33 & 3,70 \\
\hline 2012 & 23,08 & 69,23 & $\mathrm{x}$ & 30,77 & 23,08 & 48,15 & 11,11 & 33,33 & 18,52 \\
\hline 2013 & 38,46 & 69,23 & 33,33 & 30,77 & 40,00 & 51,72 & 20,69 & 31,03 & 3,45 \\
\hline Mean & 13,87 & 72,57 & 13,54 & 27,43 & 33,31 & 28,50 & 9,84 & 18,40 & 6,37 \\
\hline Median & 15,59 & 75,00 & 13,54 & 25,00 & 32,86 & 26,67 & 10,91 & 14,71 & 4,90 \\
\hline SD & 10,55 & 21,74 & 18,60 & 21,74 & 22,45 & 13,31 & 6,85 & 9,48 & 5,58 \\
\hline
\end{tabular}

Source: own study on the basis of Stock Exchange Yearbooks and Notoria Serwis SA.

In the case of companies that were listed on the Warsaw trading floor for the first time, most of them paid dividend in 2011 (50\% of newly listed companies). The high value of List $_{t}$ was also observed in the last year of research period. In 2013, this ratio stood at 33,33\%. Moreover, in most years of the analysed period the value of List $_{t}$ was equal to $0 \%$ or - due to the lack of newly listed companies in electromechanical industry sector - impossible to calculate.

The highest value of dividend payment omission ratio was observed in 2000 when $75 \%$ of dividend payers refrained from dividend payments. In 2001, 2003 and 2009, the value of $\mathrm{Omit}_{t}$ stood at 50\% and in 2012-2013 it 
was equal to $33,77 \%$ per year. The average annual value of dividend payment omission ratio amounted to $27,43 \%$, median stood at $25 \%$, and standard deviation reached the level of $21,74 \%$.

The analysis of share of the companies initiating dividend payments in the total number of payers showed that the value of Init Share t was the highest in 2001. It was equal to $75 \%$. The high value of this ratio was also observed in 2009 , when $62,5 \%$ of dividend payers accounted for the companies initiating the dividend payments. In 2000, 2004 and 2008, the value of Init Share $e_{t}$ stood at $50 \%$ per year. The average value of this ratio was equal to $33,31 \%$, median reached the level of $32,86 \%$ and standard deviation was $22,45 \%$.

Analysing the share of dividend payers (including the companies initiating and continuing payments) in the total number of companies operating in electromechanical industry sector, it should be noted that relatively many companies paid dividend in the period between 2009-2013. The highest value of Pay Total $t$ was observed in 2011 and 2013 (51,85\% and 51,72\%, respectively). In the research period, the dividend payers accounted for $28,5 \%$ of the companies operating in the examined sector. Moreover, in half of the years at least $26,67 \%$ of companies paid dividend.

The companies that initiated dividend payments accounted for $9,84 \%$ of the study population, and the companies that continued dividend payments accounted for $18,4 \%$ of the total number of companies. Median was at the level of $10,91 \%$ and $14,41 \%$, respectively, and standard deviation stood at $6,85 \%$ and $9,48 \%$, respectively.

The highest value of Omit Total $_{t}$ was observed in 2012. It was equal to $18,52 \%$. In contrast, the lowest value of this ratio occurred in 2004, 2005 and 2008. It stood at $0 \%$, which means that in those years no company resigned from dividend payment. The average annual value of this ratio stood at $6,37 \%$, median reached the level of $4,9 \%$ and standard deviation was equal to $5,58 \%$.

\section{The Results of Empirical Studies on the Occurrence of Catering Approach to Dividend Payments on the Warsaw Stock Exchange}

The highest average price-to-book value ratio, calculated for dividend payers in the period between 2000-2013, was observed in 2007. In this year, the average value of $E W p / B V$ was equal to 3,76, and the average value of $V W p / B V$ stood at 4,43 . The lowest average values of this ratio, in turn, were observed in 2001 ( 0,51 and 0,58 , respectively). The average annual value of 
$E W p / B V$ for dividend payers stood at 1,69 and $V W p / B V$ was equal to 2,38. The median amounted to 1,67 and 2,33, respectively, and standard deviation was equal to 0,94 and 1,15 , respectively.

In the case of nonpayers, the highest average value of price-to-book value ratio was observed in 2013. In this year, $E W p / B V$ amounted to 3,69. In turn, $V W p / B V$ was the highest in 2006 . It was equal to 3,79 . The average annual values were equal to 1,38 and 1,40 , respectively. Median stood at 1,12 and 1,18 , respectively (see Table 4).

Table 4. Average equal- and value-weighted price-to-book value ratios and dividend premiums in the period between 1999-2013

\begin{tabular}{|c|c|c|c|c|c|c|}
\hline \multirow{2}{*}{ Years } & \multicolumn{2}{|c|}{ Payers } & \multicolumn{2}{c|}{ Nonpayers } & \multicolumn{2}{c|}{ Dividend Premium } \\
\cline { 2 - 7 } & $(\boldsymbol{E} \boldsymbol{W} \boldsymbol{p} \boldsymbol{B} \boldsymbol{V})_{\boldsymbol{t}}$ & $(\boldsymbol{V} \boldsymbol{W} \boldsymbol{p} \boldsymbol{B} \boldsymbol{V})_{\boldsymbol{t}}$ & $(\boldsymbol{E} \boldsymbol{W} \boldsymbol{p} \boldsymbol{B} \boldsymbol{V})_{t}$ & $(\boldsymbol{V} \boldsymbol{W} \boldsymbol{p} \boldsymbol{B} \boldsymbol{V})_{\boldsymbol{t}}$ & $\boldsymbol{E} \boldsymbol{W p}_{\boldsymbol{t}}{ }^{\boldsymbol{D}-\boldsymbol{N} \boldsymbol{D}}$ & $\boldsymbol{V W}_{\boldsymbol{t}}{ }^{\boldsymbol{D}-\boldsymbol{D} \boldsymbol{D}}$ \\
\hline 1999 & 0,70 & 1,57 & 0,82 & 1,14 & $-0,12$ & 0,43 \\
\hline 2000 & 0,62 & 0,89 & 0,80 & 0,19 & $-0,18$ & 0,70 \\
\hline 2001 & 0,51 & 0,58 & 0,73 & 0,44 & $-0,22$ & 0,14 \\
\hline 2002 & 0,75 & 1,16 & 0,50 & 0,90 & 0,25 & 0,27 \\
\hline 2003 & 1,76 & 2,82 & 0,90 & 1,03 & 0,86 & 1,79 \\
\hline 2004 & 2,24 & 3,47 & 1,20 & 1,20 & 1,03 & 2,28 \\
\hline 2005 & 2,13 & 3,82 & 1,47 & 1,72 & 0,66 & 2,11 \\
\hline 2006 & 3,41 & 4,26 & 3,16 & 3,79 & 0,25 & 0,47 \\
\hline 2007 & 3,76 & 4,43 & 2,08 & 2,24 & 1,68 & 2,19 \\
\hline 2008 & 0,96 & 1,51 & 1,12 & 0,98 & $-0,17$ & 0,53 \\
\hline 2009 & 1,67 & 2,22 & 1,24 & 1,67 & 0,43 & 0,55 \\
\hline 2010 & 2,11 & 2,41 & 1,13 & 1,18 & 0,98 & 1,23 \\
\hline 2011 & 1,22 & 1,74 & 0,83 & 0,73 & 0,40 & 1,01 \\
\hline 2012 & 1,50 & 2,33 & 1,04 & 1,66 & 0,46 & 0,67 \\
\hline 2013 & 2,00 & 2,54 & 3,69 & 2,09 & $-1,69$ & 0,45 \\
\hline Mean & 1,69 & 2,38 & 1,38 & 1,40 & 0,31 & 0,99 \\
\hline Median & 1,67 & 2,33 & 1,12 & 1,18 & 0,40 & 0,67 \\
\hline SD & 0,94 & 1,15 & 0,88 & 0,84 & 0,74 & 0,72 \\
\hline
\end{tabular}

Source: own study on the basis of Stock Exchange Yearbooks and GPWInfostrefa.

The dividend premium was positive in the majority of analysed years. It means that the capital market was usually pricing dividend payers higher than nonpayers. The highest dividend premium was observed in 2007 $\left(E W p^{D-N D}\right.$ stood at 1,68 , and $V W p^{D-N D}$ was equal to 2,19$)$. The lowest equalweighted dividend premium occurred in 2013. It was equal to $-1,69$. The lowest value-weighted dividend premium, in turn, was observed in 2001. It stood at 0,14 . The average annual value of $E W p^{D-N D}$ amounted to 0,31 , and $V W p^{D-N D}$ was equal to 0,99 . Median of equal-weighted dividend premium 
stood at 0,40 , and median of value-weighted dividend premium reached the level of 0,67 .

By adopting the value of median as a reference level of the dividend premium, which is used by the companies in the process of deciding to pay (i.e. to initiate or to continue dividend payments) or not to pay dividend (including dividend omissions), the research period was divided into years of relatively high and relatively low valuation of dividend payers. For the year of relatively high valuation of dividend payers was considered that year, when the dividend premium was at least equal to the median. Otherwise, that year was considered to be the year of relatively low valuations of dividend payers. The values of equal-weighted dividend premium as well as its median are shown in Figure 4.

Figure 4. The values of equal-weighted dividend premium and its median in the period between 1999-2013

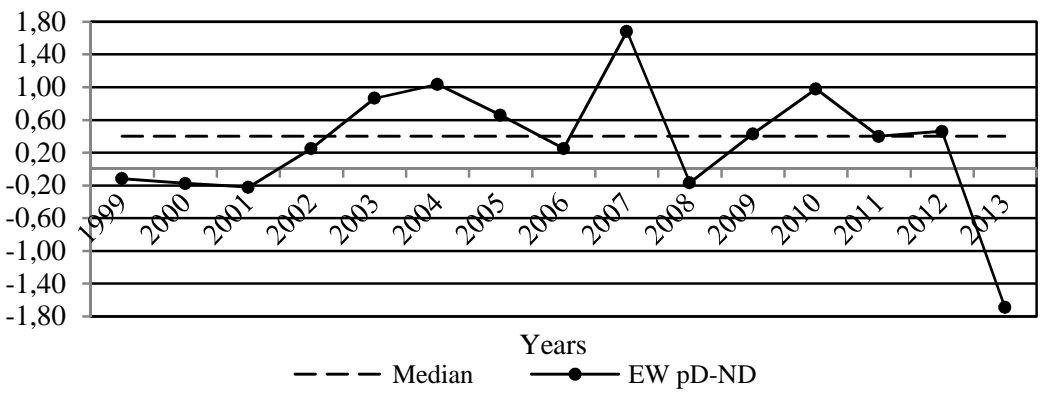

Source: own study on the basis of Stock Exchange Yearbooks and GPWInfostrefa.

Consistent with the catering approach, the decision to pay dividend is made by the company on the basis of the level of dividend premium for a previous year. For the years of relatively high equal-weighted dividend premium were considered the following years: 2003, 2004, 2005, 2007, 2009, 2010, 2011 and 2012. This means that the companies should be more likely to pay dividend in years: 2004-2006, 2008 and 2010-2013 (see Figure 4). The years of a relatively high value-weighted dividend premium are as follows: 2000, 2003, 2004, 2005, 2007, 2010, 2011 and 2012. This means that the companies should be more likely to pay dividend in the following years: 2001, 2004-2006, 2008 and 2011-2013 (see Figure 5). 
Figure 5. The values of value-weighted dividend premium and its median in the period between 1999-2013

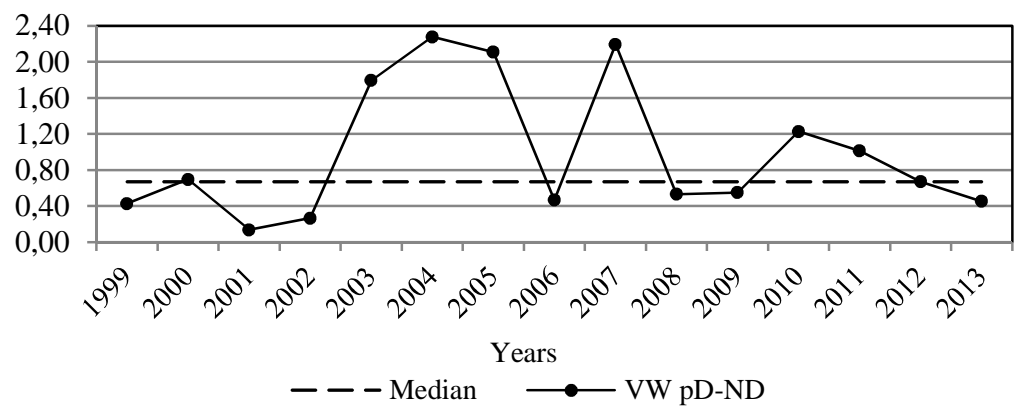

Source: own study on the basis of Stock Exchange Yearbooks and GPWInfostrefa.

The values of descriptive statistics of dividend payment ratios seem to confirm the catering activities of managers of stock companies operating in electromechanical industry sector. In the years of relatively high dividend premium (calculated in two ways) the average values of Init $t_{t}$ Cont $_{t}$ and List $_{t}$ are higher than in the years of relatively low dividend premium. In the years of relatively high valuation of dividend payers, measured with the equal-weighted dividend premium, the average dividend payment initiation ratio was equal to $17,95 \%$. In the years of relatively low dividend premium, in turn, Init $_{t}$ stood at $8,91 \%$ (see Table 5).

In the years of the relatively high dividend premium, $86,37 \%$ of dividend payers decided to continue dividend payments, while in other years Cont $_{t}$ was lower and amounted to 54,17\%. A similar relationship can be observed among the companies that were listed on the Warsaw Stock Exchange for the first time. On average, $16,67 \%$ of these companies initiated dividend payments in the years of relatively high dividend premium. If the dividend premium was low or it was negative dividend was paid only by $8,33 \%$ of newly listed companies.

Similar conclusions on the dividend catering may be drawn by analysing the values of Pay Total, Init Total , Cont Total $_{t}$ and Omit Total. The catering behaviour of companies was also confirmed by examination of the median values of these ratios in the years of relatively high and relatively low dividend premium. Moreover, the compatible findings may be formulated when using the value-weighted dividend premium (see Table 5). 
Table 5. Descriptive statistics of dividend payment ratios in the years of relatively high and low valuations of dividend payers (in \%)

\begin{tabular}{|c|c|c|c|c|c|c|c|c|c|c|}
\hline \multirow[b]{2}{*}{ 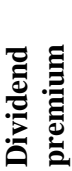 } & \multirow{2}{*}{ 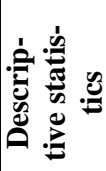 } & \multicolumn{9}{|c|}{ Dividend payment ratios } \\
\hline & & Init $_{t}$ & Cont $_{t}$ & List $_{t}$ & mit $t_{t}$ & $\begin{array}{c}\text { Init } \\
\text { Share }_{t}\end{array}$ & $\begin{array}{c}\text { Pay } \\
\text { Total }_{t}\end{array}$ & $\begin{array}{c}\text { Init } \\
\text { Total }_{t}\end{array}$ & $\begin{array}{l}\text { Cont } \\
\text { Total }_{t}\end{array}$ & $\begin{array}{c}\text { Omit } \\
\text { Total }_{t}\end{array}$ \\
\hline \multirow{8}{*}{$\sum_{i=1}^{2}$} & \multicolumn{10}{|c|}{ Years of relatively high dividend premium } \\
\hline & Mean & 17,59 & 86,37 & 16,67 & 9,78 & 31,72 & 36,55 & 11,69 & 4. & 7,42 \\
\hline & Median & 16,23 & 88,75 & 0,00 & 5,00 & 32 & 31 & 11,81 & 25,83 & 6,67 \\
\hline & SD & 10,47 & 12,69 & 21,08 & 11,52 & 15,34 & 11,33 & 6,06 & 5 & 4,83 \\
\hline & \multicolumn{10}{|c|}{ Years of relatively low dividend premium } \\
\hline & Mean & 8,91 & 54,17 & 8,33 & 45,83 & 35,42 & 17,77 & 7,36 & 10,41 & 12,38 \\
\hline & Media & 6,79 & 50,00 & 0,00 & 50,00 & 37,50 & & 5,26 & 11,24 & 13,25 \\
\hline & $\widehat{S I}$ & 0 & 17,18 & 11,79 & 17,18 & 29,24 & 6,37 & 7,05 & ,96 & 4.38 \\
\hline \multirow{8}{*}{$\frac{1}{3}$} & \multicolumn{10}{|c|}{ Years of relatively high dividend premium } \\
\hline & Mean & 17,71 & 81,68 & 16,67 & 14,47 & 37,35 & 34,72 & 12,33 & 21,93 & 6,74 \\
\hline & Median & 16,72 & 82,50 & 0,00 & 5,00 & 37,86 & 26,67 & 12,92 & 23,33 & 5,96 \\
\hline & SD & 10,47 & 17,44 & 21,08 & 17,67 & 20,91 & 12,44 & 6,19 & 10,06 & 4,70 \\
\hline & \multicolumn{10}{|c|}{ Years of relatively low dividend premium } \\
\hline & Mean & 8,74 & 60,42 & 8,33 & 39,58 & 27,92 & 20,21 & 6,52 & 13,69 & 13,29 \\
\hline & Median & 6,79 & 62,50 & 0,00 & 37,50 & 27,50 & 17,34 & 5,26 & 12,70 & 13,25 \\
\hline & SD & 8,23 & 20,94 & 11,79 & 20,94 & 23,29 & 9,30 & 6,25 & 6,00 & 3,22 \\
\hline
\end{tabular}

Source: own study on the basis of Stock Exchange Yearbooks and GPWInfostrefa.

The preliminary conclusions on the catering behaviour of companies should be verified by studying the dependence between dividend payment ratios and dividend premium. The values of Spearman's rank correlation coefficient indicate the existence of relationship between the market valuation of companies and the number of dividend payers. The strongest unidirectional dependence was observed between the dividend premium and the number of companies continuing dividend payments. The value of Spearman's rank correlation coefficient was equal to 0,78 if calculation was based on $E W p_{t-1}^{D-N D}$ and it stood at 0,63 if $V W p_{t-1}{ }^{D-N D}$ was used. A strong unidirectional dependence was also observed between the dividend premium and value of List $_{t}$. It was equal to 0,6 and 0,86, respectively. The weakest unidirectional dependence took place in the case of $\operatorname{Init}_{t}(0,04$ and 0,20, respectively). In contrast, the strongest bidirectional dependence was observed between the dividend premium and dividend payment omission ratio $\left(\mathrm{Omit}_{t}\right)$. It was equal to $-0,86$ and $-0,68$, respectively (see Table 6). 
Table 6. The values of Spearman's rank correlation coefficients for the dependence between dividend premium and dividend payment ratios

\begin{tabular}{|c|c|c|c|c|c|c|c|c|c|}
\hline $\begin{array}{l}\text { Dividend } \\
\text { premium }\end{array}$ & Init & Cont & List. & Omi & \begin{tabular}{|c|} 
Init \\
Share $_{t}$ \\
\end{tabular} & $\begin{array}{c}\text { Pay } \\
\text { Total }_{t}\end{array}$ & $\begin{array}{c}\text { Init } \\
\text { Total }_{t}\end{array}$ & $\begin{array}{c}\text { Cont } \\
\text { Total }_{t}\end{array}$ & $\begin{array}{c}\text { Omit } \\
\text { Total }_{t}\end{array}$ \\
\hline$E W p_{t-1}^{D-1}$ & 0,04 & 0,78 & 0,60 & $-0,86$ & $-0,12$ & 0,46 & 0,13 & 0,46 & $-0,52$ \\
\hline$V W p_{t-1}^{D-N D}$ & 0,20 & 0,63 & 0,86 & $-0,68$ & 0,09 & 0,45 & 0,27 & 0,36 & $-0,64$ \\
\hline
\end{tabular}

Source: own study on the basis of Stock Exchange Yearbooks and GPWInfostrefa.

The unidirectional dependence between the dividend premium and the number of dividend payers is particularly seen in the case of companies continuing dividend payments. If the dividend payers were priced higher than nonpayers in year $t$, relatively more companies continued dividend payments in year $t+1$. If the dividend premium was low or negative in year $t$, some of the companies omitted the dividend payment in the following year (see Figure 6).

Figure 6. The dividend premium $E W p_{t-1}{ }^{D-N D}$ and the value of Cont $_{t}$ (one-yearahead)

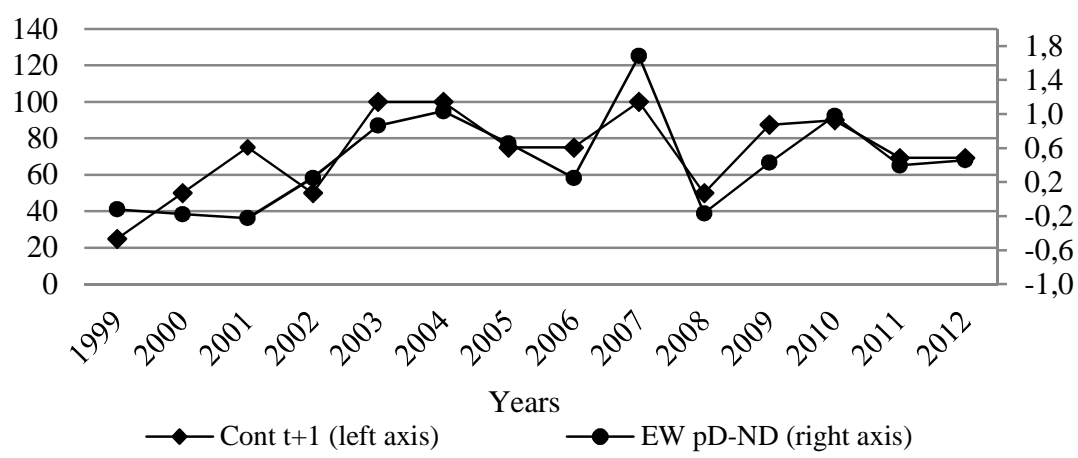

Source: own study on the basis of Stock Exchange Yearbooks and GPWInfostrefa.

On the existence of a relationship between the relative market value of dividend payers and the number of companies conducting the dividend payments indicates some of estimated values of the parameter $\beta$ in the linear regression models (positive when the dependent variable is Init $_{t}$, Cont $t_{t}$ and List $_{t}$, and negative in the case of variable Omit $_{t}$ ). If the dependent variable is the share of companies continuing dividend payment in the year $t$ in the number of dividend payers in year $t-1$, the value of the parameter $\beta$ is 
positive and statistically significant at the significance level of 0,01 . Thus, the increase in the value of the dividend premium (calculated in two ways) is accompanied by a relative increase in the number of companies continuing dividend payments. Moreover, a variability of Cont $_{t}$ is explained in the model by variability of equal-weighted dividend premium in $59 \%$ and by variability of value-weighted dividend premium in $57 \%$.

The occurrence of the catering behaviour of company is also visible in the case of $\mathrm{Omit}_{t}$, for which the value of parameter $\beta$ is negative and statistically significant at the significance level of 0,01 . In this case, the coefficient of determination amounted to $51 \%$ and $45 \%$.

If the dependent variable was Init $_{t}$ or List $_{t}$ the positive values of the parameter $\beta$ were observed. This may indicate the use of catering by managers of companies operating in electromechanical industry sector.

It should be noted that statistically significant the value of the parameter $\beta$ was obtained at a significance level of 0,05 in the case of linear regression model in which the explanatory variable was $V W p_{t-1}{ }^{D-N D}$ and the dependent variable was Init $_{t}$. However, the value of the $R^{2}$ was very low and amounted to 5\% (see Table 7).

Table 7. Estimation of linear regression models for the dependence between the dividend payment ratios and dividend premium

\begin{tabular}{|c|c|c|c|c|c|c|}
\hline \multirow{2}{*}{$\begin{array}{c}\text { Dependent } \\
\text { variable }\end{array}$} & \multicolumn{2}{|c|}{$\begin{array}{c}\text { Parameter } \boldsymbol{\beta} \\
(\boldsymbol{t} \text {-Student })\end{array}$} & \multicolumn{2}{c|}{$\begin{array}{c}\text { Intercept } \boldsymbol{\alpha} \\
(\boldsymbol{t} \text {-Student })\end{array}$} & \multicolumn{2}{c|}{$\begin{array}{c}\text { Coefficient of } \\
\text { determination } \boldsymbol{R}^{2}\end{array}$} \\
\cline { 2 - 7 } & $\boldsymbol{E} \boldsymbol{W}$ & $\boldsymbol{V} \boldsymbol{W}$ & $\boldsymbol{E} \boldsymbol{W}$ & $\boldsymbol{V} \boldsymbol{W}$ & $\boldsymbol{E} \boldsymbol{W}$ & $\boldsymbol{V W}$ \\
\hline \multirow{2}{*}{ Init $_{t}$} & $\begin{array}{c}0,28 \\
(1,07)\end{array}$ & $\begin{array}{c}0,21^{* *} \\
(0,78)\end{array}$ & $\begin{array}{c}0,95 \\
(2,63)\end{array}$ & $\begin{array}{c}0,89^{*} * * \\
(1,96)\end{array}$ & 0,09 & 0,05 \\
\hline \multirow{2}{*}{ Cont $_{t}$} & $\begin{array}{c}1,12^{*} \\
(4,17)\end{array}$ & $\begin{array}{c}1,09 * \\
(3,97)\end{array}$ & $\begin{array}{c}2,23 * \\
(6,02)\end{array}$ & $\begin{array}{c}1,68^{*} \\
(3,57)\end{array}$ & 0,59 & 0,57 \\
\hline List $_{t}$ & $\begin{array}{c}0,27 \\
(1,22)\end{array}$ & $\begin{array}{c}0,14 \\
(0,61)\end{array}$ & $\begin{array}{c}0,10 \\
(0,34)\end{array}$ & $\begin{array}{c}0,12 \\
(0,31)\end{array}$ & 0,11 & 0,03 \\
\hline \multirow{2}{*}{ Omit $_{t}$} & $\begin{array}{c}-0,48^{*} \\
(-3,55)\end{array}$ & $\begin{array}{c}-0,45^{*} \\
(-3,10)\end{array}$ & $\begin{array}{c}1,30^{*} \\
(6,92)\end{array}$ & $\begin{array}{c}1,51 * \\
(6,09)\end{array}$ & 0,51 & 0,45 \\
\hline
\end{tabular}

Symbols: * statistically significant at the significance level of $0,01, * *$ statistically significant at the significance level of $0,05, * * *$ statistically significant at the significance level of 0,10 .

Source: own study on the basis of Stock Exchange Yearbooks and GPWInfostrefa. 


\section{Conclusions}

The dividend payers operating in electromechanical industry sector in the period between 1999-2013 were valued by the investors of the Warsaw trading floor higher than non-payers. The decisions on dividend payment (both continuing and initiating dividend payments) were made more frequently in the years of relatively high dividend premium. If the dividend premium was relatively low or negative, some of the companies decided not to pay dividend. Such behaviour of stock companies may confirm that the managers take action in accordance with the catering theory of dividends. They cater to investors by paying dividends if the capital market put a stock price premium on payers. They do not pay dividends if investors prefer non-payers.

The results of the study presented in this paper are of the preliminary nature, so conclusions should not be generalized. The conducted empirical research are in statu nascendi, so it is necessary to consider the need for its intensification and extension as well as application of the other dividend payments ratios and different methods of dividend premium calculation. There is no doubt that research must be extended with the macroeconomic factors (e.g. the economic situation), the development and technological opportunities of sector as well as the investment strategies of companies.

\section{References}

Asquith, P. \& Mullins, D. (1983). The Impact of Initiating Dividend Payments on Shareholders Wealth. Journal of Business, 56(1). http://dx.doi.org/10.10 $\underline{86 / 296187 .}$.

Baker, M. \& Wurgler, J. (2004a). A Catering Theory of Dividends. The Journal of Finance, 59, http://dx.doi.org/10.1111/j.1540-6261.2004.00658.x.

Baker, M. \& Wurgler, J. (2004b). Appearing and Disappearing Dividends: the Link to Catering Incentives. Journal of Financial Economics, 73(2). http://dx.doi.org/10.1016/j.jfineco.2003.08.001.

Damodaran, A. (2007). Finanse korporacyjne. Teoria i praktyka. Gliwice: Helion.

De Rooij, M. \& Renneboog, L. (2009). The Catering Theory of Dividends. In H. K. Baker (Ed.). Dividends and Dividend Policy. Hoboken: John Wiley \& Sons.

Dhaliwal, D. S., Erickson, M. \& Trezevant, R. (1999). A Test of the Theory of Tax Clienteles for Dividend Policies. National Tax Journal, 52(2).

Duraj, A. N. (2002). Czynniki realizacji polityki wyptat dywidendy przez publiczne spótki akcyjne. Łódź: Wydawnictwo Uniwersytetu Łódzkiego.

Easterbrook, F. H. (1984). Two Agency-Cost Explanations of Dividends. American Economic Review, 74(4).

Eije H. \& Megginson,W. E. (2008). Dividends and Share Repurchases in the European Union. Journal of Financial Economics, 89. 
Fama, E. \& French, K. (2001). Disappearing Dividends: Changing Firm Characteristics or Lower Propensity to Pay?, Journal of Financial Economics, 60(1). http://dx.doi.org/10.1016/S0304-405X(01)00038-1.

Ferris, S. P., Sen, N. \& You, H. P. (2006). God Save the Queen and Her Dividends: Corporate Payouts in the UK. Journal of Business, 79(3).

Gajdka, J. (2013). Behawioralne finanse przedsiębiorstw. Łódź: Wydawnictwo Uniwersytetu Łódzkiego.

Gordon, M. J. (1959). Dividends, Earnings, and Stock Prices, The Review of Economics and Statistics, 41(2). http://dx.doi.org/10.2307/1927792.

Grullon, G., Michaely, R. \& Swaminathan, B. (2002). Dividend Changes as a Sign of Firm Maturity? Journal of Business, 75(3). http://dx.doi.org/10.10 $\underline{86 / 339889}$.

Hoberg, G. \& Prabhala, N. (2009). Disappearing Dividends: The Importance of Idiosyncratic Risk and the Irrelevance of Catering, Review of Financial Studies. 22(1).

http://www.gpwinfostrefa.pl/GPWIS2/pl/quotes/archive/1

http://ir.notoria.pl/

http://www.gpw.pl/biblioteka-gpw-lista?gpwlc_id=10

Jensen, M. C. (1986). Agency Costs of Free Cash Flow, Corporate Finance, and Takeovers. American Economic Review, 76(2).

Jiang, Z., Kim, K. A., Lie, E. \& Yang, S. (2013). Share Repurchases, Catering, and Dividend Substitution. Journal of Corporate Finance. 21. http://dx.doi.org/10. 1016/i.jcorpfin.2013.01.004.

Julio, B. \& Ikenberry, D. (2004). Reappearing Dividends. Journal of Applied Corporate Finance, 16(4). http://dx.doi.org/10.1111/j.1745-6622.2004.00010.x.

Konieczka, P. \& Szyszka, A. (2013). Teoria karmienia dywidendami na rynku amerykańskim. Journal of Management and Finance, 2(2).

Kowerski, M. (2011). Ekonomiczne uwarunkowania decyzji o wypłatach dywidend przez spótki publiczne. Kraków-Rzeszów-Zamość: Wydawnictwo Konsorcjum Akademickie.

Kulchania, M. (2013). Catering Driven Substitution in Corporate Payouts. Journal of Corporate Finance, 21, http://dx.doi.org/10.1016/j.jcorpfin.2013.02.003.

Li, K. \& Zhao, X. (2008). Asymmetric Information and Dividend Policy. Financial Management, 37(4), http://dx.doi.org/10.1111/j.1755-053X.2008.00030.x.

Lintner, J. (1962). Dividends, Earnings, Leverage, Stock Prices and Supply of Capital to Corporation. Review of Economics and Statistics, 44(3). http://dx.doi.org/10.2307/1926397.

Litzenberger, R. H. \& Ramaswamy, K. (1979), The Effects of Personal Taxes and Dividends on Capital Asset Prices: Theory and Empirical Evidence. Journal of Financial Economics, 7(2).

Miller, M. H. \& Modigliani, F. (1961), Dividend Policy, Growth, and the Valuation of Shares, Journal of Business, 34(4), http://dx.doi.org/10.1086/294442.

Mueller, D. C. (1972). A Life Cycle Theory of the Firm. Journal of Industrial Economics, 20(3). http://dx.doi.org/10.2307/2098055. 
Pieloch-Babiarz, A. (in print). Dividend Initiation as a Signal of Subsequent Earnings Performance - Warsaw trading floor evidence, Research Papers of Wroctaw University of Economics.

Sierpińska, M. (1999). Polityka dywidend w spótkach kapitatowych. Warszawa: PWN.

Tsuji, C. (2010). A Test of the Catering Theory of Dividends: The Case of the Japanese Electric Appliances Industry. Journal of Management Research, 2(2). http://dx.doi.org/10.5296/jmr.v2i2.371. 